\title{
Digestive Dysbiosis in Systemic Scleroderma: a Review
}

\author{
Ioana Bratoiu', Alexandra Burlui', Patricia Richter'1, Anca Cardoneanu', Ciprian Rezus², Elena Rezus ${ }^{1}$ \\ 1 Department of Rheumatology and Physiotherapy, "Grigore T. Popa” University of Medicine and Pharmacy, Iași, Romania \\ 2 Department of Internal Medicine, "Grigore T. Popa” University of Medicine and Pharmacy, Iași, Romania
}

\section{CORRESPONDENCE \\ Alexandra Maria Burlui \\ Str. Universității nr. 16 \\ 700115 lași, Romania \\ Tel: +40 232301615 \\ E-mail: maria-alexandra.burlui@ \\ umfiasi.ro}

\section{ARTICLE HISTORY}

Received: March 30, 2021

Accepted: April 15, 2021
Ioana Bratoiu • Str. Universității nr. 16, 700115 Iași, Romania. Tel: +40 232301 615, E-mail: ioanaharton@ yahoo.com

Patricia Richter • Str. Universității nr. 16, 700115 Iași, Romania. Tel: +40 232301615 , E-mail: patricia01paty@ yahoo.com

Anca Cardoneanu • Str. Universității nr. 16, 700115 Iași, Romania. Tel: +40 232301 615, E-mail: cardoneanu_ anca84@yahoo.com

Ciprian Rezus • Str. Universității nr. 16, 700115 Iași, Romania. Tel: +40 232301 615, E-mail: ciprianrezus@ yahoo.com

Elena Rezus • Str. Universității nr. 16, 700115 lași, Romania. Tel: +40 232301615 , E-mail: elena_rezus@ yahoo.com

\begin{abstract}
Systemic sclerosis (SSc) is a rare autoimmune disease characterized by widespread microvasculopathy, inflammation, and fibrosis of the skin and internal organs. The involvement of the gastrointestinal tract is associated with a wide variety of symptoms and affects circa $90 \%$ of patients during the course of the disease. The gastrointestinal microbiota contains trillions of microbial cells and has been found to contribute to both local and systemic homeostasis. In both health and disease, a dynamic interrelationship between gut microbiome activity and the host immune system has been identified. Gastrointestinal dysbiosis has been described as having an important role in obesity, diabetes mellitus, liver disease, cardiovascular and neuropsychiatric disorders, neoplasia, as well as autoimmunity. Recent scientific data indicates a notable role of dysbiosis in the pathogenesis of SSc-related digestive involvement together with various other clinical manifestations. The present review aims to summarize the recent findings regarding digestive dysbiosis as well as the relationship between gastrointestinal microbiota and certain features of SSC.
\end{abstract}

Keywords: systemic sclerosis, microbiota, gastrointestinal involvement, dysbiosis

\section{INTRODUCTION}

Systemic sclerosis (SSc) is an autoimmune condition with a complex pathogenesis that is characterized by vasculopathy and fibrosis of the skin as well as the internal organs. Depending on the extent of cutaneous involvement, there are three distinct subsets: limited cutaneous systemic sclerosis (lcSSc), diffuse cutaneous systemic sclerosis (dcSSc), and scleroderma "sine scleroderma". The potentially severe disease-related cutaneous, cardiopulmonary, renal, and gastrointestinal changes contribute significantly to the increased morbidity and mortality risk in SSc patients, together with a lower quality of life. Up to $90 \%$ of SSc patients develop upper and/or lower digestive involvement during the course of the disease. Despite the fact that the gastrointestinal tract can be affected in every form of SSc, it is more frequent or more severe in the diffuse phenotype. According to recent findings, dysbiosis may be involved in the development of certain gastrointestinal symptoms in SSc patients. ${ }^{1-7}$ 
The gastrointestinal microbiota contains trillions of microbial cells and has been found to contribute to both local and systemic homeostasis. ${ }^{8}$ The immune system can modulate the processes occurring within the microbial ecosystem. Additionally, the microbiota itself produces biochemically active molecules which may affect the immune system's functionality. ${ }^{9}$ Any disturbance of this balance may lead to dysbiosis which has been described as having an important role in obesity, diabetes mellitus, liver disease, cardiovascular and neuropsychiatric disorders, neoplasia, as well as in autoimmunity. ${ }^{8-12}$ Numerous different interactions between the microbiota and the host immune system have been described in immune-mediated diseases including SSc. ${ }^{13}$

The present review aims to describe the recent findings regarding dysbiosis as well as the relationship between gastrointestinal microbiota and certain features of SSc.

\section{MICROBIOTA CHANGES IN THE UPPER DIGESTIVE TRACT}

Apart from skin fibrosis and Raynaud's phenomenon (RP), one of the most common manifestations of SSc is the involvement of the gastrointestinal tract. ${ }^{1,7}$ Through a wide range of symptoms, disease-related digestive involvement has a notable impact on quality of life and demonstrates a major influence on perception of disease severity in SSc patients. $^{14}$

The oral cavity may be affected in SSc, leading to mucosal, dental, and periodontal changes. ${ }^{15,16}$ The most common orofacial changes described in these patients are microstomia, xerostomia, oral mucosal atrophy, telangiectasias, widening of the periodontal ligament, periodontitis, and bone damage involving the temporomandibular joint. ${ }^{17-19}$ Periodontal disease is an inflammatory condition defined by the presence of pathogenic microflora in the oral biofilm which disturbs the host immune response that may destroy the periodontium, causing bone resorption and ultimately leading to tooth loss. ${ }^{20} \mathrm{SSc}$ patients are at risk of developing periodontal disease due to microstomia, the latter leading to poor oral hygiene and subsequent dental plaque growth. ${ }^{21}$ During the course of periodontal disease, the facultatively anaerobic Gram-positive species may convert into anaerobic, proteolytic Gram-negative species. Moreover, potential pathogens such as Porphyromonas gingivalis or Aggregatibacter actinomycetemcomitans can trigger autoimmunity by activating autoantibody production through citrullinated antigens, this mechanism being described in autoimmune diseases such as rheumatoid arthritis. However, further research is needed to in- vestigate the connection between the bacterial species involved in periodontal disease and autoantibody production in SSc. ${ }^{21,22}$

Salivary gland involvement, clinically expressed through xerostomia, is a frequently encountered feature in SSc, more than $50 \%$ of the patients complaining of "dry mouth". ${ }^{15}$ Baron et al. showed that saliva production in these patients is decreased, thus facilitating the development of dysbiosis in the oral cavity. ${ }^{19}$ The fibrotic process appears around the capillaries and excretory ducts, promoting functional impairment by decreasing vascular permeability. Sjogren's syndrome can be associated with the condition and has been found in circa $30 \%$ of SSc patients, mostly due to the fibrotic process. ${ }^{17,23}$

Approximately $50-90 \%$ of SSc patients may develop symptoms linked to esophageal involvement. ${ }^{24-26}$ The latter has been associated to various symptoms, such as heartburn, regurgitation, dysphagia, pain, or nausea, as a result of esophageal dysmotility. $2,3,27,28$ The combination of hypotensive esophagogastric junction pressure and absent contractility in the lower esophageal body are typical features of the classic scleroderma esophagus. SSc patients who have absent contractility on high-resolution esophageal manometry experience more severe heartburn, dysphagia, chest and abdominal pain, early satiety, bloating, and loss of appetite. ${ }^{29-31}$ Moreover, up to $5 \%$ of the patients can develop Barrett's esophagus and/or adenocarcinoma. ${ }^{32,33}$

It has been stated that dysbiosis at this level may also influence the appearance of symptoms. The esophagus microbiota mostly consists of bacteria from the oral cavity and from the stomach, the more prevalent species being Streptococcus viridans, Fusobacterium spp., Neisseria spp., and Haemophilus spp. The dynamics of the esophageal microbiome is not fully understood, although an increase in Gram-negative bacteria is presumed to be connected with gastroesophageal reflux disease (GERD), Barrett's esophagus, and treatment with proton pump inhibitors. ${ }^{34,35}$ Espinoza et al. described the esophagus microbiota in patients with SSc, concluding that the samples from SSc patients were less abundant in species such as Lactobacillus, Bacillus, and Rhodococcus. ${ }^{36}$

Patients with SSc may experience nausea, vomiting, early satiety, heartburn, bloating, and abdominal pain due to gastroesophageal dysmotility. ${ }^{4,26}$ It has been shown that infection with Helicobacter pylori $(H$. pylori) is frequent and could be a risk factor for the appearance of certain digestive symptoms in SSc. ${ }^{37} \mathrm{H}$. pylori is a Gram-negative bacterium that commonly infects the gastric mucosa through virulence factors, triggering and maintaining an inflammatory response and eventually promoting the development 
of cross-reactive antibodies against bacterial proteins by molecular mimicry. ${ }^{38}$ Several studies (presented in Table 1) have revealed an increased prevalence of $H$. pylori infection in SSc patients, indicating possible links between certain clinical features (including digestive symptoms) and H. pylori infection. ${ }^{39}$ Furthermore, a relationship between $H$. pylori infection and the severity of skin involvement has been suggested despite the fact that no link has been found with the peripheral vascular damage. ${ }^{40}$

\section{MICROBIOTA CHANGES IN THE LOWER DIGESTIVE TRACT}

Small bowel involvement has been linked to pseudo-obstruction and small intestinal bacterial overgrowth (SIBO) in SSc. Patients may experience nausea, emesis, bloating, abdominal pain or distension, diarrhea, and malabsorption, the latter leading to weight loss and various nutrient deficiencies. ${ }^{26}$ The most important defensive system against SIBO is the integrity of the intestinal motor activity. There are several studies which showed that the SScrelated fibrosis of the bowel smooth muscle (impacting its functionality) and vasculopathy may promote bacterial overgrowth. ${ }^{46,47}$

The prevalence of SIBO in SSc was analyzed in many studies, as seen in Table 2, its prevalence spanning between $13 \%$ and $65 \%$, with higher values in Western areas compared to Asian countries. ${ }^{49}$ Patients with SIBO complain more frequently of abdominal pain/discomfort, bloating, diarrhea or constipation compared to healthy controls (HC). ${ }^{50}$ Furthermore, patients with SIBO have higher levels of fecal calprotectin (a bowel inflammatory marker)..$^{50}$ Approximately $10 \%$ of SSc patients can develop malnutrition, ${ }^{51}$ with lower levels of serum albumin and vitamin B12 and reduced quality of life. ${ }^{49,51}$

Regarding the microbiota composition in SSc and SIBO patients, a study published in 2019 reported an abundance of Odoribacter, Bilophila and Lachnospira species, finding

TABLE 1. The relationship between SSc and $H$. pylori infection

\begin{tabular}{|c|c|c|c|}
\hline Study & Patients & Evaluation & Results \\
\hline $\begin{array}{l}\text { Yamaguchi et al., } \\
2008^{41}\end{array}$ & 64 patients & $\begin{array}{l}\text { Upper gastrointestinal } \\
\text { endoscopy } \\
\text { Anti-H. pylori lgG antibodies } \\
\text { (serum samples) }\end{array}$ & $\begin{array}{l}29 \text { of } 64 \text { participants were diagnosed with } \\
\text { esophagitis. } 37 \text { patients }(57.8 \%) \text { were found } \\
\text { positive for } H \text {. pylori infection of which } 10 \text { had reflux } \\
\text { esophagitis. The prevalence of reflux esophagitis } \\
\text { was lower than in } H \text {. pylori negative patients. }\end{array}$ \\
\hline Radić et al., $2013^{40}$ & $\begin{array}{l}42 \text { patients ( } 2 \text { with IcSSc and } 40 \\
\text { with dcSSc) }\end{array}$ & $\begin{array}{l}\text { Upper gastrointestinal } \\
\text { endoscopy and rapid urease } \\
\text { test }\end{array}$ & $\begin{array}{l}\text { The prevalence of } H \text {. pylori infection was } 62 \% \\
(26 \text { positive patients, } 1 \text { with IcSSc and } 25 \text { with } \\
\text { dcSSc) with significant differences in the digestive } \\
\text { involvement between positive and negative patients. } \\
\text { The study described a possible relation between } \\
\text { H. pylori infection status and skin involvement, } \\
\text { positive patients having more severe mRSS score. } \\
\text { Furthermore, } H \text {. pylori positive SSc patients had a } \\
\text { more severe lung and heart involvement. }\end{array}$ \\
\hline Ram et al., $2013^{42}$ & $\begin{array}{l}79 \text { SSc patients (from a total } \\
\text { of } 1,290 \text { subjects with various } \\
\text { autoimmune diseases) }\end{array}$ & Anti-H. pylori lgG antibodies & $\begin{array}{l}\text { The authors found a } 55.7 \% \text { prevalence in SSc } \\
\text { patients. }\end{array}$ \\
\hline Bilgin et al., $2015^{43}$ & $\begin{array}{l}30 \text { SSc patients (18 with IcSSc } \\
\text { and } 12 \text { with dcSSc) } \\
\text { versus } \\
30 \mathrm{HC}\end{array}$ & $\begin{array}{l}\text { Anti-H. pylori lgG and IgM } \\
\text { antibodies }\end{array}$ & $\begin{array}{l}73.3 \% \text { of SSc patients were positive ( } 72.2 \% \text { with } \\
\text { IcSSc and } 75 \% \text { with dcSSc), whereas only } 46.6 \% \\
\text { from the control group had positive IgG antibodies. }\end{array}$ \\
\hline Balaji et al., 201744 & $\begin{array}{l}55 \text { SSc patients ( } 23 \text { with IcSSc } \\
\text { and } 32 \text { with dcSSc) } \\
\text { versus } \\
25 \mathrm{HC}\end{array}$ & Anti-H. pylori lgG antibodies & $\begin{array}{l}61.8 \% \text { of SSc patients were found to be positive } \\
\text { compared to } 24 \% \text { in the HC group. Anti-H. pylori } \\
\text { antibody levels were higher in SSc patients with } \\
\text { digestive symptoms, yet did not differ according to } \\
\text { disease phenotype. }\end{array}$ \\
\hline $\begin{array}{l}\text { Efthymiou et al., } \\
202045\end{array}$ & $\begin{array}{l}91 \text { patients ( } 41 \text { with dcSSc and } \\
50 \text { with IcSSc) } \\
\text { versus } \\
59 \mathrm{HC}\end{array}$ & $\begin{array}{l}\text { Anti-H. pylori antigen-specific } \\
\text { antibody testing }\end{array}$ & $\begin{array}{l}67 \%(68.3 \% \text { in dcSSc patients and } 66 \% \text { in IcSSc } \\
\text { patients) compared with } 76.3 \% \text { in } \mathrm{HC} \text {. }\end{array}$ \\
\hline
\end{tabular}


TABLE 2. The investigation of SIBO in SSc patients

\begin{tabular}{|c|c|c|c|}
\hline Study & Patients & Evaluation & Results \\
\hline Parodi et al., 200853 & $\begin{array}{l}55 \text { patients (18 with dcSSc and } \\
37 \text { with IcSSc) } \\
\text { versus } \\
60 \mathrm{HC}\end{array}$ & Lactulose breath test & $\begin{array}{l}54.5 \% \text { tested positive ( } 30 / 55 \text { compared to } 4 / 60 \\
\text { positive } \mathrm{HC}) \text {. }\end{array}$ \\
\hline Marie et al., 200949 & $\begin{array}{l}51 \text { patients ( } 25 \text { with dcSSc and } \\
26 \text { with IcSSc) }\end{array}$ & $\begin{array}{l}\text { Glucose hydrogen and methane } \\
\text { breath test }\end{array}$ & $\begin{array}{l}43.1 \% \text { tested positive. Among the } 22 \text { patients with } \\
\text { SIBO, } 11 \text { also exhibited abnormal small bowel } \\
\text { manometry. }\end{array}$ \\
\hline Fynne et al., 201154 & 15 patients with dcSSc & Hydrogen breath test & $\begin{array}{l}3 \text { patients tested positive according to the breath } \\
\text { test. }\end{array}$ \\
\hline $\begin{array}{l}\text { Gemignani et al., } \\
2013^{55}\end{array}$ & $\begin{array}{l}50 \text { patients ( } 18 \text { with dcSSc and } \\
32 \text { with IcSSc) } \\
\text { versus } \\
60 \mathrm{HC}\end{array}$ & Glucose breath test & $\begin{array}{l}18 \% \text { from the SSc group and } 5 \% \text { from the HC group } \\
\text { were diagnosed with SIBO. }\end{array}$ \\
\hline Savarino et al., $2013^{56}$ & $\begin{array}{l}99 \text { patients ( } 31 \text { with dcSSc and } \\
68 \text { with IcSSc) } \\
\text { versus } \\
60 \text { HC }\end{array}$ & Lactulose breath test & $\begin{array}{l}\text { In the SSc group, } 46 \% \text { tested positive compared to } \\
5 \% \text { of controls. }\end{array}$ \\
\hline Tauber et al., 201457 & $\begin{array}{l}38 \text { patients ( } 18 \text { with dcSSc and } \\
20 \text { with IcSSc) }\end{array}$ & $\begin{array}{l}\text { Glucose hydrogen and methane } \\
\text { breath test }\end{array}$ & $\begin{array}{l}37 \% \text { tested positive at the breath test, } 37 \% \text { also } \\
\text { exhibiting gastrointestinal involvement. }\end{array}$ \\
\hline Soukup et al., 201458 & 37 patients & Hydrogen breath test & $37.8 \%$ tested positive. \\
\hline Marie et al., $2015^{59}$ & $\begin{array}{l}125 \text { patients ( } 43 \text { with dcSSc and } \\
82 \text { with IcSSc) }\end{array}$ & $\begin{array}{l}\text { Glucose hydrogen and methane } \\
\text { breath test and fecal calprotectin }\end{array}$ & $\begin{array}{l}46.2 \% \text { tested positive. Patients with higher levels } \\
\text { of fecal calprotectin experienced more severe } \\
\text { gastrointestinal symptoms. }\end{array}$ \\
\hline Adarsh et al., 201760 & $\begin{array}{l}50 \text { patients ( } 34 \text { with IcSSc and } \\
16 \text { with dcSSc), of which } 37 \\
\text { underwent a lactulose breath } \\
\text { test }\end{array}$ & Lactulose breath test & $\begin{array}{l}21 \% \text { of the } 37 \text { participants who underwent lactulose } \\
\text { breath test were positive. }\end{array}$ \\
\hline $\begin{array}{l}\text { Cruz-Dominguez et al., } \\
201761\end{array}$ & $\begin{array}{l}68 \text { patients ( } 41 \text { with IcSSc and } 27 \\
\text { with dcSSc) }\end{array}$ & $\begin{array}{l}\text { Glucose/lactulose hydrogen } \\
\text { breath test }\end{array}$ & $\begin{array}{l}64.7 \% \text { tested positive, the breath test being linked to } \\
\text { the severity of symptoms. }\end{array}$ \\
\hline $\begin{array}{l}\text { Sawadpanich et al., } \\
201962\end{array}$ & $\begin{array}{l}89 \text { patients with non-digestive } \\
\text { symptoms ( } 65 \text { with dcSSc and } \\
24 \text { IcSSc) }\end{array}$ & $\begin{array}{l}\text { Glucose hydrogen and methane } \\
\text { breath test }\end{array}$ & $\begin{array}{l}12 \text { patients tested positive for SIBO (the only } \\
\text { statistically significant correlation was between } \\
\text { disease duration and SIBO) }\end{array}$ \\
\hline $\begin{array}{l}\text { Polkowska-Pruszyńska } \\
\text { et al., } 202050\end{array}$ & $\begin{array}{l}40 \text { patients ( } 6 \text { with dcSSc and } 33 \\
\text { with IcSSc) } \\
\text { versus } \\
39 \mathrm{HC}\end{array}$ & Lactulose hydrogen breath test & $\begin{array}{l}47.5 \% \text { tested positive compared to only } 12.8 \% \text { in } \mathrm{HC} \text {. } \\
\text { Fecal calprotectin levels were higher in the study } \\
\text { group, particularly in the SSc - SIBO patients. }\end{array}$ \\
\hline $\begin{array}{l}\text { García-Collinot et al., } \\
202063\end{array}$ & $\begin{array}{l}74 \text { patients ( } 43 \text { with IcSSc and } \\
32 \text { with dcSSc) }\end{array}$ & Lactulose hydrogen breath test & Results showed a positivity rate of $64.9 \%$. \\
\hline
\end{tabular}

$\mathrm{HC}$ - healthy controls

a considerably higher bacterial abundance and diversity compared to SSc patients without SIBO. ${ }^{52}$

Colonic involvement is often asymptomatic, although some patients may exhibit diarrhea, constipation, tenesmus, painful defecation, and fecal incontinence. There are various studies, presented in Table 3, on patients with SSc with or without gastrointestinal involvement, which described their gut microbiota compared to $\mathrm{HC}$ and explored the potential relationship between gastrointestinal symptoms and dysbiosis in this respect. ${ }^{64}$ The studies performed on SSc patients' gut microbiota showed an increase in Lactobacillus expression, a commensal microbe whose role in gut peristalsis remains unknown. Moreover, recent research described a decrease in certain beneficial commensal genera (Clostridium, Faecalibacterium, and Bacteroides) and an increase in potentially pathobiont genera (Fusobacterium, Prevotella, Ruminococcus). ${ }^{65-71}$

Volkmann et al. analyzed the cecum and sigmoid mucosal lavage samples from SSc patients. The authors described the following changes: patients displayed an abun- 
TABLE 3. The alteration of large bowel microbiota in SSc

\begin{tabular}{|c|c|c|c|c|}
\hline Study & Evaluation & Patients & Increased* & Decreased* \\
\hline Volkmann et al., 201665 & $\begin{array}{l}\text { Cecum and sigmoid mucosal } \\
\text { lavage samples }\end{array}$ & $\begin{array}{l}17 \mathrm{SSc} \\
\text { versus } \\
\mathrm{HC}\end{array}$ & $\begin{array}{l}\text { Lactobacillus } \\
\text { Bifidobacterium } \\
\text { Fusobacterium } \\
\text { Erwinia } \\
\text { Ruminococcus } \\
\text { Prevotella }\end{array}$ & $\begin{array}{l}\text { Faecalibacterium } \\
\text { Clostridium } \\
\text { Rikenella } \\
\text { Bacteroides fragilis }\end{array}$ \\
\hline $\begin{array}{l}\text { Andrnasson et al., } \\
201666\end{array}$ & Fecal samples & $\begin{array}{l}98 \text { SSc } \\
\text { versus } \\
\mathrm{HC}\end{array}$ & Lactobacillus & $\begin{array}{l}\text { Faecalibacterium prausnitzii } \\
\text { Clostridiaceae }\end{array}$ \\
\hline Bosello et al., 201667 & Fecal samples & $\begin{array}{l}66 \text { SSc } \\
\text { versus } \\
\mathrm{HC}\end{array}$ & $\begin{array}{l}\text { Lactobacillus } \\
\text { Ruminococcus } \\
\text { Roseburia } \\
\text { Faecalibacterium }\end{array}$ & $\begin{array}{l}\text { Clostridium } \\
\text { Odoribacter } \\
\text { Veilonella } \\
\text { Prevotella }\end{array}$ \\
\hline \multirow[t]{2}{*}{ Volkmann et al., 201768} & Fecal samples & $\begin{array}{l}17 \text { SSc } \\
\text { versus } \\
\text { HC } \\
\text { (Norway) }\end{array}$ & Lactobacillus & $\begin{array}{l}\text { Clostriudium } \\
\text { Bacteroides }\end{array}$ \\
\hline & & $\begin{array}{l}17 \mathrm{SSC} \\
\text { versus HC } \\
\text { (USA) }\end{array}$ & $\begin{array}{l}\text { Lactobacillus } \\
\text { Fusobacterium } \\
\text { Erwinia } \\
\text { Akkermansia } \\
\text { Ruminococcus }\end{array}$ & $\begin{array}{l}\text { Faecalibacterium } \\
\text { Bacteroides }\end{array}$ \\
\hline Patrone et al., 201769 & Fecal samples & $\begin{array}{l}18 \mathrm{SSC} \\
\text { versus } \\
\mathrm{HC}\end{array}$ & $\begin{array}{l}\text { Blautia } \\
\text { Lactobacillus } \\
\text { Eubacterium } \\
\text { Bacteroides } \\
\text { Acinetobacter }\end{array}$ & $\begin{array}{l}\text { Roseburia } \\
\text { Clostridium } \\
\text { Ruminococcus } \\
\text { Streptococcus }\end{array}$ \\
\hline Bellocchi et al., 201870 & Fecal samples & $\begin{array}{l}59 \text { SSc } \\
\text { versus } \\
\mathrm{HC}\end{array}$ & $\begin{array}{l}\text { Fonticella } \\
\text { Parabacterioides } \\
\text { Unidentified members of the } \\
\text { Firmicutes phylum } \\
\text { Butyricimonas } \\
\text { Desulfovibrio }\end{array}$ & $\begin{array}{l}\text { Turicibacter } \\
\text { Unidentified members of the } \\
\text { Lachnospiraceae family }\end{array}$ \\
\hline Natalello et al., 202071 & Fecal samples & $\begin{array}{l}63 \text { SSc } \\
\text { versus } \\
\mathrm{HC}\end{array}$ & $\begin{array}{l}\text { Firmicutes } \\
\text { Streptococcus } \\
\text { Lactobacillus } \\
\text { Blautia } \\
\text { Ruminococcus } \\
\text { Phascolarctobacterium }\end{array}$ & $\begin{array}{l}\text { Sutterella } \\
\text { Bacteroides } \\
\text { Odoribacter } \\
\text { Roseburia }\end{array}$ \\
\hline
\end{tabular}

* relative to the control group; $\mathrm{HC}$ - healthy controls; USA - United States of America

dance of Lactobacillus, Bifidobacterium, Fusobacterium, Erwinia, Ruminococcus, and Prevotella, and a decrease in Faecalibacterium, Clostridium, Rikenella, and Bacteroides fragilis. ${ }^{65}$ In 2017, Volkmann et al. compared two independent SSc cohorts from Norway and the USA, providing evidence that gut microbiota varies between the two populations, the extent of dysbiosis being greater in the American cohort. It has been stated that an increased expression of species such as Ruminococcus or Akkermansia may contribute to the fibrotic process in scleroderma patients, yet further studies are needed to confirm this relationship. ${ }^{66,68}$
Regarding gastrointestinal involvement, it has been shown that patients with none to mild gastrointestinal tract involvement had increased abundance of Bacteroides fragilis and Clostridium, while patients with moderate to severe gastrointestinal symptoms had an increase of Prevotella and Fusobacterium species. ${ }^{72}$ Patrone et al. conducted a study comparing HC to SSc patients with/without gastrointestinal involvement. ${ }^{69}$ The results showed that the diversity and richness of the gut microbiota varied significantly between controls and SSc patients with gastrointestinal involvement, albeit there were no differences between healthy individuals and SSc patients with- 
out digestive involvement. The group without gastrointestinal symptoms had a lower level of Blautia, Dorea, and Bacteroides compared with the other patients. Dorea is a gas-producing bacterium, and its high levels could explain the abdominal bloating experienced by SSc patients with gastrointestinal involvement. ${ }^{69}$ Bellocchi et al. conducted a study on 59 subjects diagnosed with SSc, suggesting a possible connection between treatment and the gut microbiota profile in these patients. ${ }^{70}$

\section{CONCLUSIONS}

SSc is an autoimmune disease with a complex pathogenesis and a wide range of symptoms derived from multiple organ involvement. Recent studies indicate an interrelationship between the activation of the immune system and the disturbance of gastrointestinal tract microbiota in various immune-inflammatory diseases including SSc. Moreover, the reported data indicate an association between dysbiosis and gastrointestinal as well as non-digestive manifestations in SSc patients. Further research is needed to elucidate the dynamics between digestive microbiota and SSc progress (pertaining to both gastrointestinal and non-digestive manifestations), focusing on the development of strategies to improve clinical outcomes and quality of life in these patients.

\section{CONFLICT OF INTEREST}

Nothing to disclose.

\section{REFERENCES}

1. McMahan ZH, Hummers LK. Gastrointestinal involvement in systemic sclerosis: diagnosis and management. Curr Opin Rheumatol. 2018;30:533 540.

2. Denaxas K, Ladas SD, Karamanolis GP. Evaluation and management of esophageal manifestations in systemic sclerosis. Ann Gastroenterol. 2018;31:1-6.

3. Tétreault MP, Kahrilas P. GI Manifestations With a Focus on the Esophagus: Recent Progress in Understanding Pathogenesis. Curr Rheumatol Rep. 2019:21:42.

4. Miller JB, Gandhi N, Clarke J, McMahan Z. Gastrointestinal Involvement in Systemic Sclerosis: An Update. J Clin Rheumatol. 2018;24:328-337.

5. Schmeiser T, Saar P, Jin D, et al. Profile of gastrointestinal involvement in patients with systemic sclerosis. Rheumatol Int. 2012;32:2471-2478.

6. Ferreli C, Gasparini G, Parodi A, Cozzani E, Rongioletti F, Atzori L. Cutaneous Manifestations of Scleroderma and Scleroderma-Like Disorders: a Comprehensive Review. Clinic Rev Allerg Immunol. 2017;53:306-336.

7. Anton E. Current management of the gastrointestinal complications of systemic sclerosis. Nat Rev Gastroenterol Hepatol. 2016;13:461-472.

8. Lynch S, Pedersen O. The Human Intestinal Microbiome in Health and Disease. N Engl J Med. 2016;375:2369-2379.

9. Vogelzang A, Guerrini MM, Minato N, Fagarasan S. Microbiota - an amplifier of autoimmunity. Curr Opin Immunol. 2018;55:15-21.

10. Tallota R, Atzeni F, Ditto MC, Gerardi MC, Sarzi-Puttini P. The Microbiome in Connective Tissue Diseases and Vasculitides: An Update Narrative Review. J Immunol Res. 2017; 2017:6836498.
11. Tong Y, Marion T, Schett G, Luo Y, Liu Y. Microbiota and metabolites in rheumatic diseases. Autoimmun Rev. 2020;19:102530.

12. Konig MF. The microbiome in autoimmune rheumatic disease. Best Pract Res Clin Rheumatol. 2020;34:101473.

13. Asano Y. The Pathogenesis of Systemic Sclerosis: An Understanding Based on a Common Pathologic Cascade across Multiple Organs and Additional Organ-Specific Pathologies. J Clin Med. 2020;9:2687.

14. Frantz C, Avouac J, Distler O, et al. Impaired quality of life in systemic sclerosis and patient perception of the disease: A large international survey. Semin Arthritis Rheum. 2016;46:115-123.

15. Smirani R, Poursac N, Naveau A, Schaeverbeke T, Devillard R, Truchetet ME. Orofacial consequences of systemic sclerosis: A systematic review. $J$ Scleroderma Relat Disord. 2018;3:88-90.

16. Hadj Said M, Foletti J, Graillon N, Guyot L, Chossegros C. Orofacial manifestations of scleroderma. A literature review. Rev Stomatol Chir Maxillofac Chir Orale. 2016;117:322-326.

17. Jung $S$, Martin T, Schmittbuhl M, Huck O. The spectrum of orofacial manifestations in systemic sclerosis: a challenging management. Oral Dis. 2017;23:424-439.

18. Gomes da Silva G, Maymone de Melo M, Leão J, et al. Oral features of systemic sclerosis: A case control study. Oral Dis. 2019;25:1995-2002.

19. Baron M, Hudson M, Tatibouet S, et al. The Canadian systemic sclerosis oral health study: orofacial manifestations and oral health-related quality of life in systemic sclerosis compared with the general population. Rheumatology (Oxford). 2014;53:1386-1394.

20. Pihlstrom BL, Michalowicz BS, Johnson NW. Periodontal diseases. Lancet. 2005;366:1809-1820.

21. Isola G, Williams RC, Lo Gullo A, et al. Risk association between scleroderma disease characteristics, periodontitis, and tooth loss. Clin Rheumatol. 2017;36:2733-2741.

22. Cheng Z, Meade J, Mankia K, Emery P, Devine DA. Periodontal disease and periodontal bacteria as triggers for rheumatoid arthritis. Best Pract Res Clin Rheumatol. 2017;31:1-12

23. Kobak S, Oskel F, Aksu K, Kabasakal Y. The frequency of sicca symptoms and Sjogren's syndrome in patients with systemic sclerosis. Int J Rheum Dis. 2013;16:88-92.

24. Denaxas K, Ladas SD, Karamanolis GP. Evaluation and management of esophageal manifestations in systemic sclerosis. Ann Gastroenterol. 2018;31:165-170.

25. Roberts CGP, Hummers LK, Ravich WJ, Wigley FM, Hutchins GM. A casecontrol study of the pathology of oesophageal disease in systemic sclerosis (scleroderma). Gut. 2006;55:1697-1703.

26. Kumar S, Singh J, Rattan S, DiMarino A, Cohen S, Jimenez S. Review article: pathogenesis and clinical manifestations of gastrointestinal involvement in systemic sclerosis. Aliment Pharmacol Ther. 2017;45:883-898.

27. Lee JS, Kim HS, Moon JR, et al. Esophageal involvement and Determinants of Perception of Esophageal Symptoms Among South Koreans With Systemic Sclerosis. J Neurogastroenterol Motil. 2020;26:477-485.

28. Arana-Guajardo AC, Barrera-Torres G, Villarreal-Alarcón MÁ, Vega-Morales $D$, Esquivel-Valerio JA. Esophageal symptoms and their lack of association with high-resolution manometry in systemic sclerosis patients. Reumato/ Clin. 2017:15:165-169.

29. Crowell MD, Umar SB, Griffing LW, DiBase JK, Lacy BE, Vela MF. Esophageal Motor Abnormalities in Patients With Scleroderma: Heterogeneity, Risk Factors, and Effects on Quality of Life. Clin Gastroenterol Hepatol. 2017;15:207-213

30. De Carlan M, Lescoat A, Brochard C, et al. Association between clinical manifestations of systemic sclerosis and esophageal dysmotility assessed by high-resolution manometry. J Scleroderma Relat Disord. 2017;2:50-56.

31. Nicola S, Rolla G, Bucca C, et al. Gastric Juice Expression of Th-17 and T-Reg Related Cytokines in Scleroderma Esophageal Involvement. Cells. 2020;19;2106

32. Snyder DL, Crowell MD, Kahn A, Griffing WL, Umar S, Ramirez FC. Prevalence of Barrett's Esophagus in Female Patients With Scleroderma. Am J Gastroenterol. 2020;116:517-521.

33. Petcu A, Ghib LJ, Grad SM, et al. Upper gastrointestinal involvement in systemic sclerosis: Findings in a real-life setting. Exp Ther Med. 2019;18:5095-5100.

34. Grusell NE, Dahlén G, Ruth M, et al. Bacterial flora of the human oral cavity, and the upper and lower esophagus. Dis Esophagus. 2012;53:650-656.

35. D'Souza SM, Cundra LB, Yoo BS, Parekh PJ, Johnson DA. Microbiome and Gastroesophageal Disease: Pathogenesis and Implications for Therapy. Ann Clin Gastroenterol Hepatol. 2020;4:020-033. 
36. Espinoza M, Mehta BK, Wang Y, et al. Characterization of the Esophageal Microbiome in Patients with Systemic Sclerosis (SSc). Arthritis Rheumatol. 2018;Suppl70.

37. Hong BY, Giang R, Mbuagbaw L, Larche M, Thabane L. Factors associated with development of gastrointestinal problems in patients with scleroderma: a systematic review. Syst Rev. 2015;4:188.

38. Radić M. Role of Helicobacter pylori infection in autoimmune systemic rheumatic diseases. World J Gastroenterol. 2014;20:12839-12846.

39. Yong W, Upala S, Sanguankeo A. Helicobacter pylori infection in systemic sclerosis: a systematic review and meta-analysis of observational studies. Clin Exp Rheumatol. 2018;36(Suppl.113): S168-S174.

40. Radić M, Kaliterna MD, Bonacin D, et al. Is Helicobacter pylori infection a risk factor for disease severity in systemic sclerosis? Rheumatol Int. 2013;33:2943-2948

41. Yamaguchi K, Iwakiri R, Hara M, et al. Reflux Esophagitis and Helicobacter pylori Infection in Patients with Scleroderma. Inter Med. 2008;47:1555-1559.

42. Ram M, Barzilai O, Shapira Y, et al. Helicobacter pylori serology in autoimmune diseases: fact or fiction? Clin Chem Lab Med. 2013;51:10751082

43. Bilgin $\mathrm{H}$, Kocabaș $\mathrm{H}$, Keșli R. The prevalence of infectious agents in patients with systemic sclerosis. Turk J Med Sci. 2015;45:1192-1197.

44. Balaji C, Bhuvanesh M, Saranya C, Ramesh R, Saravanan M, Rajeswari S Helicobacter Pylori infection in Systemic Sclerosis and Its Association with Upper Gastrointestinal Dysfunction. Indian J Rheumatol. 2017;12:204-208.

45. Efthymiou G, Liaskos C, Siamopoulou T, et al. Antigen-specific humoral responses against Helicobacter pylori in patients with systemic sclerosis. Immunol Res. 2020;68:39-47.

46. Quigley EM. Small Intestinal Dysmotility, Its Role in Irritable Bowel Syndrome and Small Intestinal Bacterial Overgrowth: Assessment and Management. Front Gastrointest Res Basel Karger. 2014;33:55-64.

47. Rawn S, Pitman N, Beattie K, Bazzaz A, Larche M. Small Intestinal Bacterial Overgrowth in Patients with Systemic Sclerosis. Indian J Rheumatol. 2017;12:S167-S170.

48. Feng $X, L i X Q$, Jiang $Z$. Prevalence and predictors of small intestinal bacterial overgrowth in systemic sclerosis: a systematic review and metaanalysis. Clin Rheumatol. 2021 January. [Epub ahead of print]

49. Marie I, Ducrotté P, Denis P, Menard JF, Levesque H. Small Intestinal bacterial overgrowth in systemic sclerosis. Rheumatology. 2009;48:1314-1319.

50. Polkowska-Pruszyńska B, Gerkowicz A, Rawicz-Pruszyński K, Krasowska D. The Role of Fecal Calprotectin in Patients with Systemic Sclerosis and Small Intestinal Bacterial Overgrowth (SIBO). Diagnostics. 2020;10:587.

51. Preis E, Franz K, Siegert E, et al. The impact of malnutrition on quality of life in patients with systemic sclerosis. Eur J Clin Nutr. 2018;72:504-510.

52. Zou H, De Palma G, Bercik P, Verdu E, Beattie K, Larche M. Distinc Characteristics of the Gut Microbiome of Patients with Systemic Sclerosis and Small Intestinal Bacterial Overgrowth [abstract]. Arthritis Rheumatol. 2019;71(suppl10).

53. Parodi A, Sessarego M, Greco A, et al. Small Intestinal Bacterial Overgrowth in Patients Suffering From Scleroderma: Clinical Effectiveness of Its Eradication. Am J Gastroenetrol. 2008;103: 1257-1262.

54. Fynne L, Worsøe J, Gregersen T, Schalageter V, Laurberg S, Krogh K. Gastrointestinal transit in patients with systemic sclerosis. Scand $J$ Gastroenterol. 2011;46:1187-1193
55. Gemignani L, Savarino V, Ghio M, et al. Lactulose Breath Test to Assess Orocecal Transit Delay and Estimate Esophageal Dysmotility in Scleroderma Patients. Semin Arthritis Rheum. 2013;42:522-529.

56. Savarino E, Mei F, Parodi A, et al. Gastrointestinal motility disorder assessment in systemic sclerosis. Rheumatology. 2013;52:1095-1100.

57. Tauber M, Avouac J, Benahmed A, et al. Prevalence and predictors of small intestinal bacterial overgrowth in systemic sclerosis patients with gastrointestinal symptoms. Clin Exp Rheumatol. 2014;32:S82-S87.

58. Soukup T, Cyrany J, Kopacova M, Tacheci I, Bures J. Small intestinal bacterial overgrowth in patients with systemic sclerosis, clinical data relevance [abstract]. Clin and Exp Rheumatol. 2014;32:S132.

59. Marie I, Leroi A, Menard J, Levesque H, Quillard M, Ducrotte P. Fecal calprotectin in systemic sclerosis and review of the literature. Autoimmun Rev. 2015;14:547-554.

60. Adarsh M, Sharma S, Sinha S, et al. Gastrointestinal Dysmotility and Infections in Systemic Sclerosis - An Indian Scenario. Curr Rheumatol Rev. 2017;13.

61. Cruz-Dominguez M, Garcia-Collinot G, Madrigal-Santillan E, et al. Small intestinal bacterial overgrowth in relation to gastrointestinal symptoms in systemic sclerosis [abstract]. Ann Rheum Dis. 2017;103:1282.

62. Sawadpanich K, Soison P, Chunlertrith K, et al. Prevalence and associated factors of small intestinal bacterial overgrowth among systemic sclerosis patients. Int J Rheum Dis. 2019;22:695-699.

63. García-Collinot G, Madrigal-Santillán EO, Martínez-Benzomo MA, et al. Effectiveness of Saccharomyces boulardii and Metronidazole for Small Intestinal Bacterial Overgrowth in Systemic Sclerosis. Dig Dis Sci. 2020;65:1134-1143.

64. Zhang X, Chen Bd, Zhao Ld, Li H. The Gut Microbiota: Emerging Evidence in Autoimmune Diseases. Trends Mol Med. 2020;26:862-873.

65. Volkmann E, Chang Y, Barroso N, et al. Association of Systemic Sclerosis With a Unique Colonic Microbial Consortium. Arthritis Rheumatol. 2016;68:1483-1492

66. Andrnasson K, Alrawi Z, Persson A, Jonsson G, Marsal J. Intestinal dysbiosis is common in systemic sclerosis and associated with gastrointestinal and extraintestinal features of disease. Arthritis Res Ther. 2016;18:278.

67. Bosello S, Paroni Sterbini F, Natalello G, et al. The intestinal involvement in systemic sclerosis is characterized by a peculiar gut microbiota [abstract]. Arthritis Rheumatol. 2016;68.

68. Volkmann E, Hoffman-Vold A, Chang Y, et al. Systemic sclerosis is associated with alterations in gastrointestinal microbiota in two independent cohorts. BMJ Open Gastroenterol. 2017;4: e000134.

69. Patrone V, Puglisi E, Cardinali M, et al. Gut microbiota profile in systemic sclerosis patients with and without clinical evidence of gastrointestinal involvement. Sci Rep. 2017;7:14874.

70. Bellocchi C, Fernandez-Ochoa A, Montanelli G, et al. Microbial and metabolic multi-omic correlations in systemic sclerosis patients. Ann N Y Acad Sci. 2018;1421:97-109.

71. Natalello G, Bosello S, Paroni Sterbini F, et al. Gut microbiota analysis in systemic sclerosis according to disease characteristics and nutritional status. Clin Exp Rheumatol. 2020;38(Suppl. 125).

72. Bellocchi C, Volkmann ER. Update on the Gastrointestinal Microbiome in Systemic Sclerosis. Curr Rheumatol Rep. 2018;20:49. 